\title{
ZASOBY DZIEDZICTWA KULTUROWEGO MAEYCH MIAST W POLSCE I ICH ZNACZENIE W KRAJOZNAWSTWIE
}

\section{Wstęp}

Krajoznawstwo to wszechstronne poznawanie danego kraju lub regionu i popularyzowanie wiedzy o nim, m.in. poprzez różne formy turystyki. Jest ono treścią programu poznawczo-wychowawczego turystyki (Kruczek, Kurek, Nowacki, 2012). Połączenie obu tych nauk odgrywa kluczową rolę w procesie poznania i poszerzania wiedzy o kraju i tożsamości kulturowej, w wyniku bezpośredniego kontaktu z dziedzictwem narodowym. Zabytki kultury materialnej są istotnym walorem krajoznawczym, decydującym o rozwoju turystyki poznawczej.

Na obszarach miejskich za elementy ważne, decydujące o atrakcyjności pod kątem rozwoju turystyki, uznaje się walory architektoniczne oraz układ urbanistyczny. Szczególnie istotnymi zabytkami są zespoły architektury $\mathrm{w}$ formie dzielnic historycznych, obiekty sakralne, a także budynki związane z tzw. kulturą wysoką (muzea, galerie, opery, teatry) oraz sportowo-rekreacyjne i handlowe. Elementy te funkcjonują w powiązaniu z odpowiednio rozwiniętą pod względem ilościowym i jakościowym bazą noclegową (Bajgier-Kowalska, Rettinger, 2014; Faracik, Kurek, Mika, Pawlusiński, 2015). Materialne dziedzictwo kulturowe miast jest najbardziej dostrzegalnym elementem różnicującym ich potencjał turystyczny, szczególnie w dobie postępującej unifikacji i uniformizacji miejskich struktur (Kaczmarek, Stasiak, Włodarczyk, 2010; Mika, 2011). Dziedzictwo kulturowe jest ważnym czynnikiem wpływającym na wybór destynacji turystycznej. 
Atrakcyjność turystyczna małych miast może wynikać z ich przeszłości historycznej, dawnych funkcji oraz struktury etnicznej ludności i związanych z tym zasobów dziedzictwa kulturowego. Właśnie te elementy w większości tworzą krajobraz kulturowy polskich miast, szczególnie tych małych, w których tradycyjne czynniki miastotwórcze są słabo wykształcone (Kwiatek-Sołtys, 2017). Rola dziedzictwa kulturowego w przypadku mniejszych ośrodków miejskich jest często marginalizowana zarówno w literaturze przedmiotu, jak i w odniesieniu do ich rozwoju, szczególnie tam, gdzie nie można z tego dziedzictwa czerpać bezpośrednich korzyści ekonomicznych (Rudan, 2010). Według McMorrana (2008) jest ono wykorzystywane, ponieważ przynosi dochód i spełnia oczekiwania turystów, a nie ze względu na fakt, że powinno zostać zachowane jako kluczowy świadek przeszłości. W wymiarze lokalnym turystyka kulturowa może odnosić się do dziedzictwa, środowiska, rękodzieła, języka, gastronomii, sztuki i muzyki, technologii, religii, edukacji oraz stroju (Jamieson, 1993). Steele (2017) zauważa, że obecnie, jak nigdy dotąd, turystyka w małych miastach ma szansę na rozwój, ze względu na rosnący popyt na turystykę wiejską. Zapotrzebowanie na lokalne produkty, a także chęć doświadczenia małomiasteczkowego życia to główne przyczyny powstania wielu nowych typów podróżowania, związanych z ruchami Slow Food oraz Cittaslow, agroturystyką czy turystyką dziedzictwa kulturowego.

Artykuł ma na celu ukazanie, jak duży jest zasób obiektów dziedzictwa kulturowego w małych miastach w Polsce, oraz przeprowadzenie ich waloryzacji pod względem znajdujących się w nich historycznych układów urbanistycznych, zespołów zamkowo-pałacowych i klasztornych, które mają decydujące znaczenie w rozwoju turystyki krajoznawczej.

\section{Obszar i metoda badań}

Sieć miejska w Polsce obejmuje 940 miast (stan na 2019 r.), w tym 722 małe miasta - o zaludnieniu nieprzekraczającym 20 tys. mieszkańców. Kryterium wielkościowe małego miasta na takim poziomie jest powszechnie uznawane przez geografów osadnictwa za granicę pomiędzy ośrodkami małymi a średniej wielkości (Kwiatek-Sołtys, 2011, 2017). Małe miasta w Polsce stanowią 76,8\% wszystkich miast, a zamieszkane są przez niewiele ponad $5 \mathrm{mln}$ osób, co stanowi 21,7\% ludności miejskiej w Polsce i 13\% zaludnienia całego kraju. Nierównomierna gęstości sieci miejskiej wynika z uwarunkowań historycznych. Zbiór małych miast w Polsce jest niejednorodny, a ich zróżnicowanie wiąże się z genezą powstania 
(od ośrodków średniowiecznych po zupełnie nowe, założone w XXI w.), wielkością (od liczących niewiele ponad 300 osób do 20 tys. mieszkańców) oraz rozlicznymi funkcjami. W grupie małych miast znajdują się ośrodki pełniące zróżnicowane funkcje, od przemysłowych po usługowe, w tym turystyczno-wypoczynkowe, uzdrowiskowe i pielgrzymkowe. Wiele spośród badanych miejsc stanowi centra podstawowych usług dla ludności z otaczających je obszarów (Kwiatek-Sołtys, 2011).

W dobie globalizacji władze małych miast poszukują nowych możliwości rozwoju społeczno-gospodarczego. W wielu z tych miejscowości trwa kryzys zarówno społeczny, wynikający z odpływu ludności, jak i gospodarczy, wiążący się z zanikiem niektórych funkcji miejskich - obsługa zaplecza wiejskiego i sektora rolniczego oraz konkurencja większych miast i centrów handlowo-usługowych. $Z$ tego powodu władze małych miast szansę na aktywizację gospodarczą upatrują $\mathrm{w}$ rozwoju turystyki.

Najistotniejszym czynnikiem kształtującym obecność zabytkowych obiektów dziedzictwa kulturowego w miastach jest ich historia. Małe miasta są w tym zakresie niezmiernie zróżnicowane (rys. 1).

Najstarsze lokacje miejskie sięgają 1211 r. (Złotoryja). W XIII w. prawa miejskie po raz pierwszy uzyskało 161 istniejących obecnie małych miast $(22,3 \%)$, a do końca okresu średniowiecza prawa miejskie miało łącznie aż 64,4\% dzisiejszych małych miast (465 miejscowości). Rozmieszczenie najstarszych miejskich ośrodków nawiązuje do zachodzących procesów urbanizacyjnych. Lokacja kolejnych 121 znanych współcześnie małych miast sięga okresu pomiędzy XVI a XVIII w. Na początku XIX stulecia sieć miejska na ziemiach polskich była już zatem gęsta, a miasta - relatywnie regularnie rozmieszczone (Jelonek, 1967). W XIX w. przeprowadzono lokację 11 istniejących obecnie małych miast, pozostałe wówczas utworzone (zdecydowana większość) pod wpływem czynnika uprzemysłowienia zmieniły się w średnie i duże ośrodki. W XX i XXI w. powstało 125 zróżnicowanych małych miast. Zaledwie 9 z nich (Aleksandrów Kujawski, Łapy, Ciechocinek, Kartuzy, Pelplin, Krzeszowice, Krzyż Wielkopolski, Skórcz i Witnica) uzyskało prawa miejskie przed wybuchem II wojny światowej ${ }^{1}$,

\footnotetext{
${ }^{1}$ Nietypowym przykładem jest tu Pelplin, który dopiero w 1931 r. uzyskał prawa miejskie jako dawna osada wyrosła przy średniowiecznym opactwie cystersów, zlikwidowanym w 1823 r. Już od XV w. osada podklasztorna pełniła funkcje miejskie. Co prawda, później doszły inne impulsy rozwojowe (od 1824 r. siedziba biskupstwa, następnie czynnik uprzemysłowienia), ale to właśnie rozwój osady służebnej przy klasztorze był głównym czynnikiem sprawczym powstania późniejszego miasta. Inny nietypowy przykład kształtowania się funkcji miejskich reprezentują przyklasztorne Kartuzy w województwie
} 


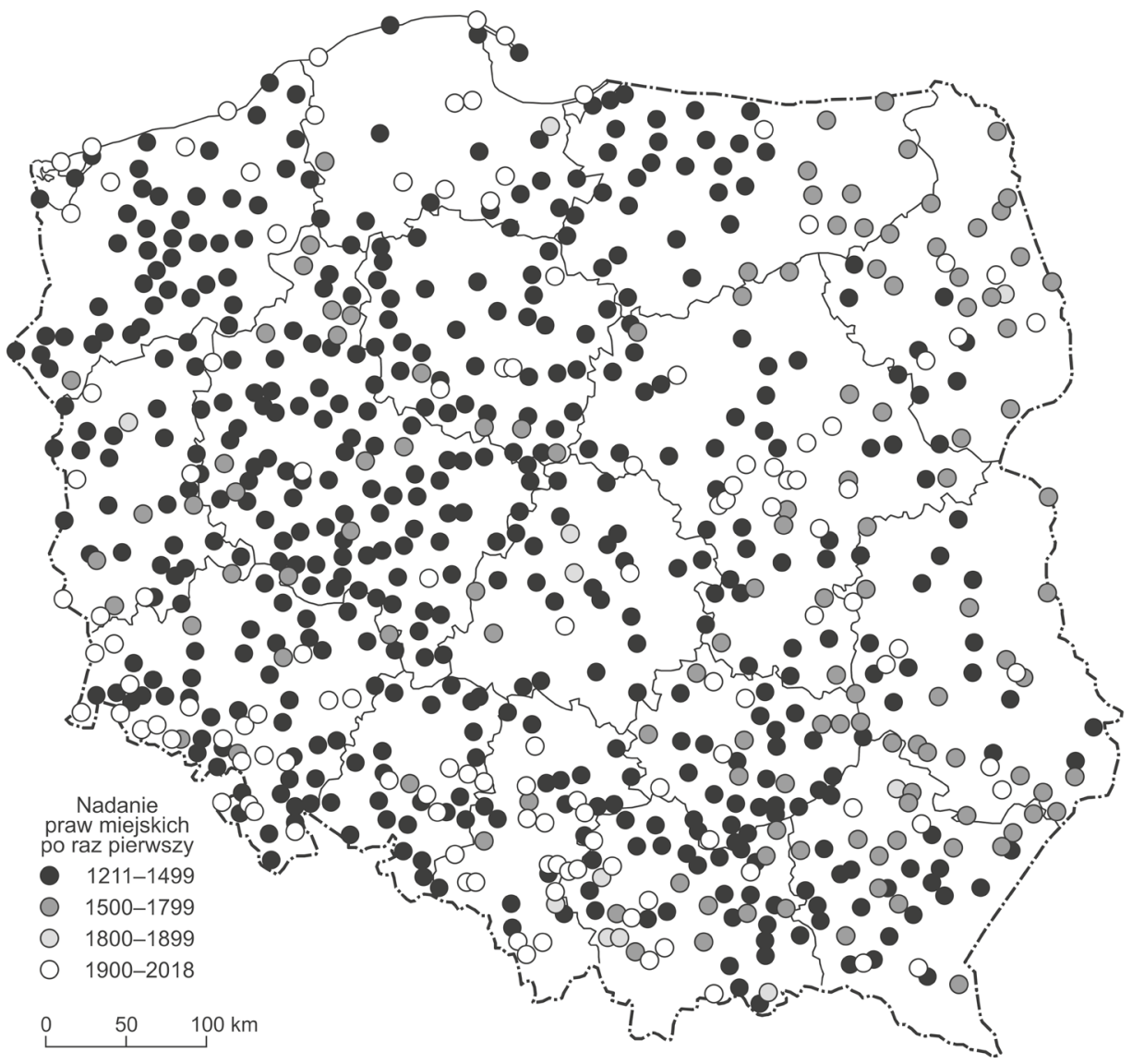

Rysunek 1. Geneza małych miast w Polsce według ich stanu na 2019 r.

Źródło: opracowanie własne

pozostałe otrzymały formalne prawa dopiero po niej - zatem należy je zaliczyć do miast nowych. Są wśród nich liczne ośrodki fabryczne, czy też miasta wykształcone przy dużych węzłach kolejowych. Z okresem powojennym wiąże się również nadanie formalnych praw miejskich wielu polskim uzdrowiskom.

Trzeba w tym miejscu nadmienić, iż nie wszystkie miasta pełniły funkcje miejskie nieprzerwanie. Ponad $1 / 3$ obecnych małych ośrodków utraciła prawa miejskie i ponownie je otrzymała w XX lub XXI w. Przykładem może tu być Wiślica, która straciła prawa miejskie w 1870 r., a odzyskała w 2018 r.

pomorskim, które wprawdzie uzyskały prawa miejskie dopiero w 1923 r., ale już od 1818 r. były stolicą powiatu pruskiego. 
Wszystkie małe miasta w Polsce (722) zostały poddane analizie pod kątem liczby i rodzaju obiektów zabytkowych, wpisanych do rejestru zabytków nieruchomych Narodowego Instytutu Dziedzictwa, według stanu na 30 września 2019 r. W celu określenia znaczenia małych miast w Polsce w rozwoju turystyki krajoznawczej zastosowano metodę waloryzacji, opierając się na systemie punktacji. Polega ona na przypisaniu poszczególnym cechom jakościowym (obiektom zabytkowym) odpowiedniej liczby punktów, według ustalonej skali wartości (Warszyńska, 1970). Mimo iż jest to ocena przybliżona, dzięki niej można wyznaczyć miasta o dużych walorach krajoznawczych i przeprowadzić porównania zasobów kulturowych. Dokonując oceny małych miast pod względem zasobów obiektów zabytkowych, po pięć punktów przyznano miastom, na których terenie znajdują się historyczne zespoły urbanistyczne, zespoły klasztorne oraz zamkowe lub pałacowe, przyciągające $\mathrm{z}$ reguły największą liczbę turystów i stanowiące ważne punkty na krajoznawczej mapie Polski. Za występowanie zabytkowych zespołów architektonicznych miasto mogło uzyskać maksymalnie 15 punktów. Dodatkowo po jednym punkcie przyznawano, jeśli w mieście były obiekty w danej kategorii zabytków, wydzielanych przez Narodowy Instytut Dziedzictwa: obiekty sakralne, obronne, zamki lub ruiny zamków, budowle użyteczności publicznej, rezydencjonalne (pałace i dwory), folwarczne, gospodarcze, mieszkalne, przemysłowe, zieleń, cmentarze i inne. Dla potencjalnego turysty ważniejsze jest to, czy w mieście są obiekty zabytkowe w danej kategorii, niż sama liczba tych obiektów. Za występowanie zabytków w wydzielonych kategoriach miasto mogło zatem łącznie uzyskać 12 punktów, a więc w sumie maksymalnie 27 punktów. Konieczność dokonania takiej waloryzacji wynikała z niejednolitych kryteriów wpisu do rejestru zabytków. Przykładowo w niektórych miastach jednym wpisem objęty został cały zespół urbanistyczny wraz z miejską zabudową a w innych - jeden wpis dotyczył zespołu urbanistycznego, a drugi poszczególnych kamienic w tym zespole (Zestawienia zabytków nieruchomych, 2019).

\section{Zasoby dziedzictwa kulturowego małych miast}

Na obszarach miejskich za główne elementy składowe, decydujące o potencjale i atrakcyjności miast w odniesieniu do rozwoju turystyki krajoznawczej, uznaje się ich walory architektoniczne oraz układ urbanistyczny, w tym szczególnie zespoły zabytkowej architektury (Faracik, Kurek, Mika, Pawlusiński, 2015; Kaczmarek, Stasiak, Włodarczyk, 2010; 
Mika, 2011). Na terenie wielu małych miast w Polsce istnieje duży zasób obiektów dziedzictwa kulturowego. Są to układy urbanistyczne, zespoły kościelne oraz klasztorne, cerkwie i synagogi, kalwarie i cmentarze, zamki i pałace, zespoły rezydencjonalne (królewskie, magnackie), zabytki sztuki ogrodowej, obiekty i uformowania obronne, zabytki architektury świeckiej, m.in. ratusze, kamienice mieszczańskie, spichlerze, zabytki techniki $\mathrm{i}$ inne. Wymienione zabytki występują w zespołach architektoniczno-urbanistycznych lub pojedynczo, w związku z czym ich rola w generowaniu ruchu turystycznego jest zróżnicowana. $Z$ kolei o ich wartości decyduje czas, rola w dziejach narodu, poziom artystyczny, a także sto-

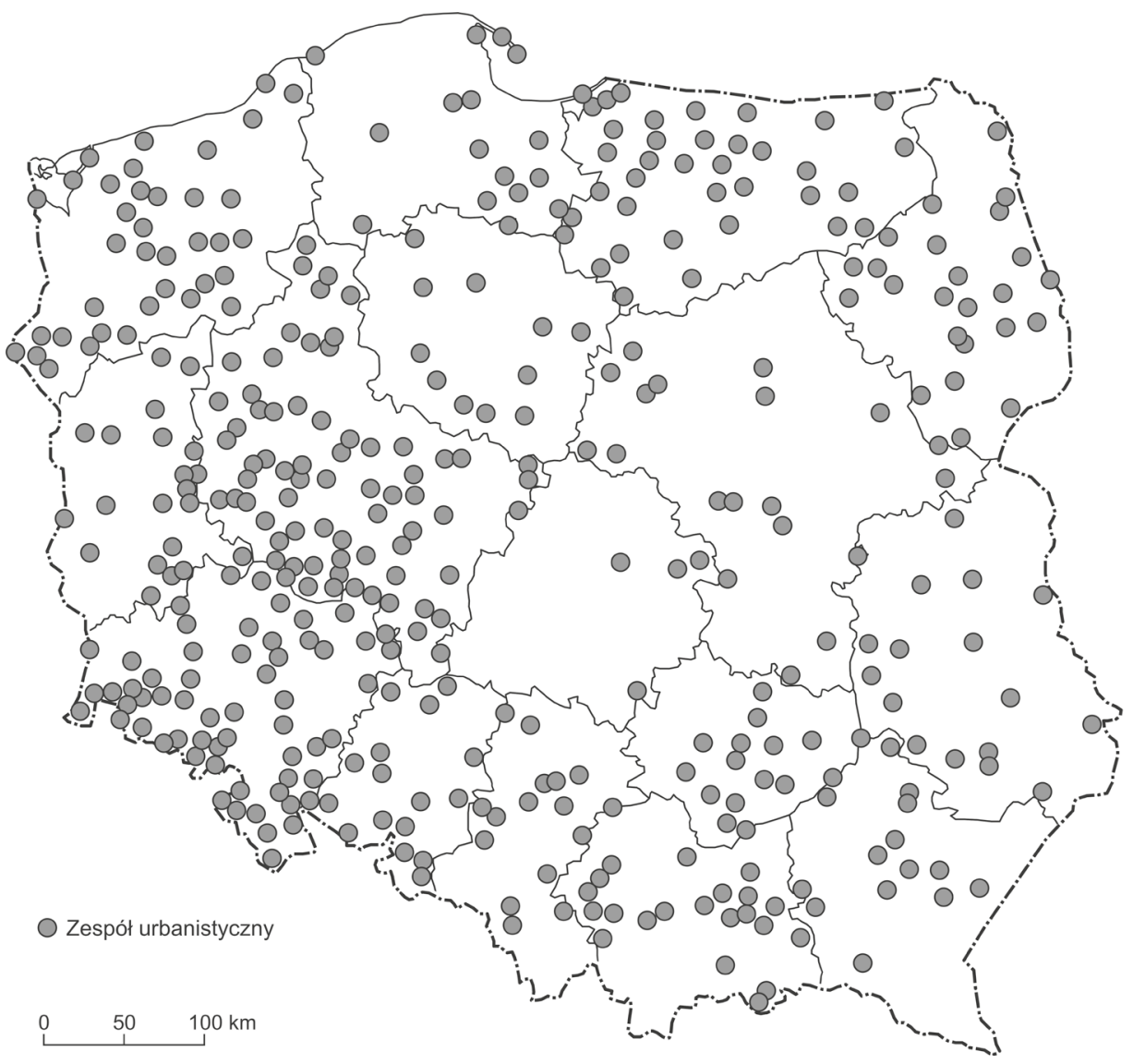

Rysunek 2. Występowanie historycznych zespołów urbanistycznych $\mathrm{w}$ małych miastach $\mathrm{w}$ Polsce według stanu miast oraz wpisu do rejestru zabytków nieruchomych

Narodowego Instytutu Dziedzictwa z 2019 r. Źródło: opracowanie własne 
pień autentyczności wobec późniejszych przekształceń, szczególnie po II wojnie światowej (Kuśnierz, Kuśnierz-Krupa, 2015). Do najcenniejszych z nich trzeba zaliczyć obiekty wpisane na listę światowego dziedzictwa kultury i natury UNESCO, przy czym tylko dwa z 16 polskich obiektów wpisanych na listę UNESCO znajdują się w małych miastach. Są to wyróżniająca się wybitnymi walorami artystycznymi, przestrzennymi i kompozycyjnymi Kalwaria Zebrzydowska oraz Łęknica z transgranicznym parkiem Mużakowskim.

Zachowane zabytkowe układy urbanistyczne są szczególnie ważnym walorem krajoznawczym, zwłaszcza w małych ośrodkach miejskich, $\mathrm{w}$ których niejednokrotnie do dziś pozostał w niezmienionej formie układ rynku, wychodzących z niego ulic, a często także małomiasteczkowa zabudowa. Te fragmenty małych miast poddawane są współcześnie procesom rewitalizacji lub odnowy, co sprawia, że stają się bardzo atrakcyjnymi przestrzeniami dla turystów. Miejski układ urbanistyczny został wpisany do rejestru zabytków w przypadku 397 małych miast w kraju (rys. 2). Najmniej małych miast z zachowanym historycznym układem urbanistycznym występuje w województwach środkowej Polski: łódzkim, mazowieckim i kujawsko-pomorskim.

Oprócz całych układów urbanistycznych istotne wydaje się również występowanie w miastach zabytkowych zespołów pałacowych i zamkowych. Tego typu obiekty są zachowane w bardzo różnym stanie i często należą do prywatnych osób, które nie zawsze udostępniają swoją własność zwiedzającym. Niemniej jednak w wielu przypadkach takie zespoły pozostają wizytówką małych miast, uwzględnianą w ich turystycznej promocji. Niektóre z nich pełnią funkcje hotelowe, muzealne czy kulturalne. Zespoły pałacowe lub zamkowe wpisane jako zespół do rejestru zabytków przez Narodowy Instytut Dziedzictwa znajdują się w 135 małych miastach (rys. 3).

Nie znaczy to, że w innych miastach nie występują pałace lub zamki, tylko że nie są one sklasyfikowane jako zabytkowe zespoły, a jedynie pojedyncze obiekty. Zespoły pałacowe lub zamkowe znajdują się w małych miastach wszystkich województw, choć ich większe nagromadzenie odnotowano w województwach: wielkopolskim i dolnośląskim (po 23), podkarpackim (15), lubelskim (11) i mazowieckim (10). Do szczególnie ciekawych pod tym względem należy Wojcieszów w województwie dolnośląskim w Górach Kaczawskich, ponieważ odnotowano tam aż cztery takie zespoły, a ich pochodzenie datuje się na okres od XVI do XIX w.

$\mathrm{W}$ analizie potencjału turystycznego małych miast, $\mathrm{z}$ uwagi na występowanie zabytkowych zespołów architektonicznych, ważne miejsce 


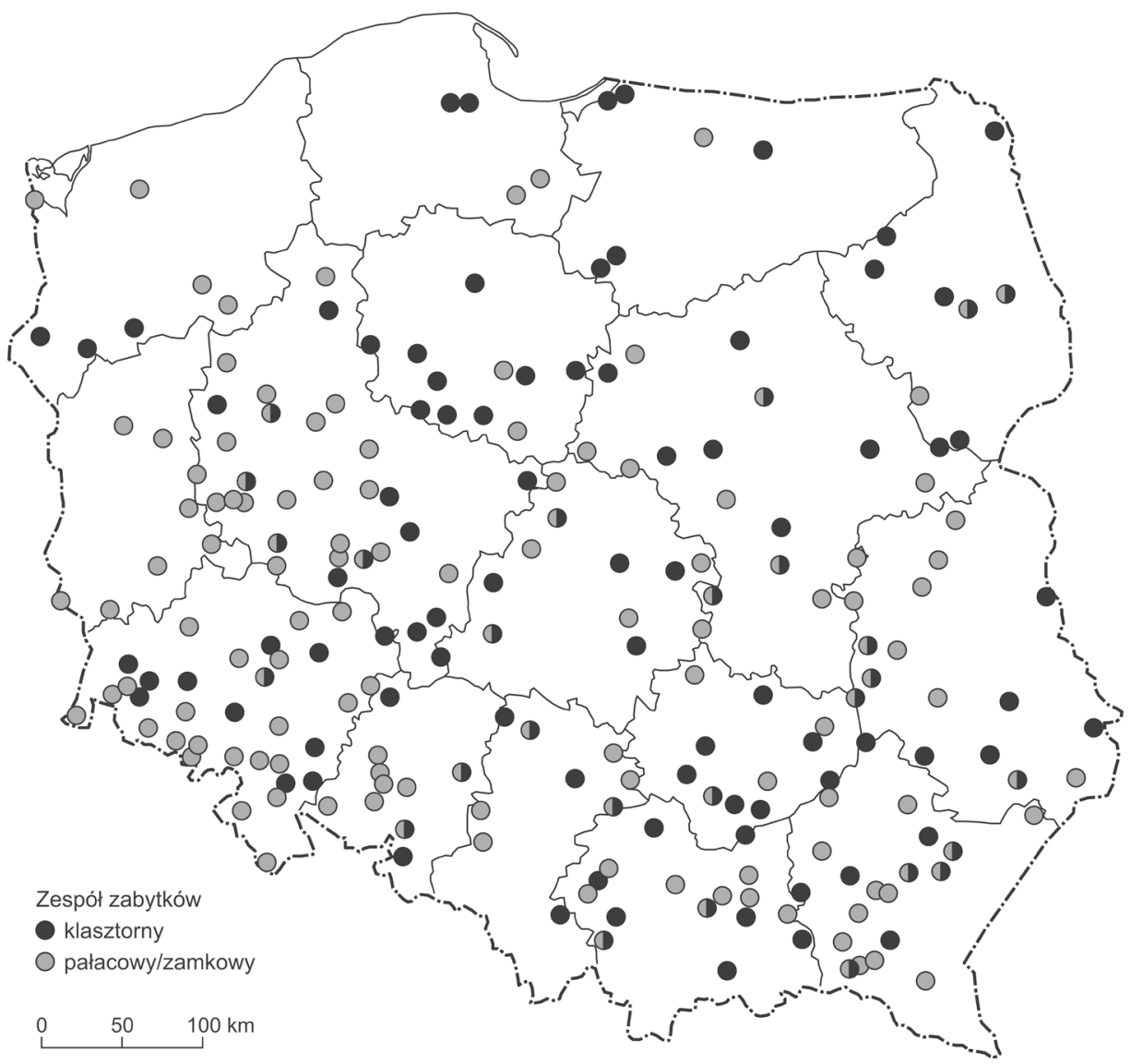

Rysunek 3. Występowanie zabytkowych zespołów pałacowych lub zamkowych oraz klasztornych w małych miastach w Polsce według stanu miast oraz wpisu do rejestru zabytków nieruchomych Narodowego Instytutu Dziedzictwa z 2019 r. Źródło: opracowanie własne

zajmują zespoły klasztorne. To one niejednokrotnie przyczyniły się do powstania tam miast, które w pierwszych wiekach swojego istnienia były osadami obsługującymi ruch pielgrzymkowy do ośrodków kultu religijnego, a funkcja kultu stała się czynnikiem miastotwórczym (Rajman, 1998). Doskonałymi przykładami mogą tu być wspomniana już wcześniej Kalwaria Zebrzydowska oraz Pelplin, który rozwinął się przy klasztorze cystersów, a prawa miejskie uzyskał dopiero w 1931 r. Zespoły klasztorne wpisane do rejestru zabytków nieruchomych występują w 116 małych miastach w Polsce (rys. 3). Do miast, w których znajdują się trzy zespoły klasztorne, należy Drohiczyn, z zespołami: Benedyktynek, Jezuitów 
i Franciszkanów; Krasnystaw z dwoma zespołami: Augustianów i klasztorem Jezuitów; Przeworsk z zespołami: Bernardynów, Bożogrobców oraz Sióstr Miłosierdzia.

Warto zwrócić uwagę na małe miasta mające historyczny układ urbanistyczny wraz z zespołami klasztornymi oraz pałacowymi lub zamkowymi, wpisanymi do rejestru zabytków. W całym kraju jest zaledwie 19 takich miejsc. Zaliczane są do nich m.in.: Kazimierz Dolny, z silnie rozwiniętą funkcją turystyczną, Łańcut czy Środa Śląska.

Za pewnego rodzaju podsumowanie badań nad rolą obiektów dziedzictwa kulturowego w małych miastach i ich znaczeniem w krajoznawstwie można uznać przeprowadzoną przez autorki artykułu waloryzację małych miast, które podzielono na pięć kategorii (typów). Jak zaznaczono w części wstępnej opracowania, w tym podziale zostały uwzględnione wszystkie obiekty wpisane do rejestru zabytków nieruchomych. Przypomnieć należy, iż zespoły urbanistyczne, klasztorne, pałacowe i zamkowe otrzymywały $\mathrm{w}$ przeprowadzonym postępowaniu waloryzacyjnym odpowiednio więcej punktów niż pojedyncze obiekty. Z tego też powodu małym miastom, w których odnotowano zróżnicowane zespoły zabytkowe, $\mathrm{z}$ reguły przyznawano w ogólnej waloryzacji najwięcej punktów.

Miasta o największych zasobach dziedzictwa kulturowego rozmieszczone są na całym terytorium Polski. Największa koncentracja miast bogatych w obiekty zabytkowe nawiązuje jednak do historii urbanizacji na ziemiach polskich (rys. 1 i 4). Do pierwszego typu zaliczono 127 małych miast, które uzyskały najwięcej punktów w przeprowadzonym postępowaniu waloryzacyjnym. Ponad $80 \%$ z nich to ośrodki, których początki sięgają średniowiecznych lokacji (rys. 4).

Wśród miast o najwyższej liczbie uzyskanych punktów znalazły się m.in. znane ośrodki turystyczne o zasięgu ponadlokalnym, wspomniany wcześniej Kazimierz Dolny, Łańcut oraz Kalwaria Zebrzydowska, której manierystyczny zespół architektoniczny i krajobrazowy oraz park pielgrzymkowy zostały wpisane w 1999 r. na listę światowego dziedzictwa kulturalnego UNESCO. Przykładem miasta zajmującego wysoką pozycję w omawianej waloryzacji (22 pkt) jest również Chełmno, które w ostatnim czasie z powodu zmniejszającej się liczby ludności dołączyło do grupy miast małych. Na uwagę zasługują ponad to: średniowieczny Przeworsk (24 pkt), Głogówek, Pińczów, Pułtusk i Środa Śląska (po 23 pkt).

Do pierwszej kategorii zaliczono także kilka ośrodków relatywnie młodych, których formalna historia miejska sięga tylko XX w., jednak istnieją w nich zróżnicowane formy architektoniczne (np. zespoły dworskie i pałacowe lub uzdrowiskowe oraz kościoły i klasztory). Ciekawym 


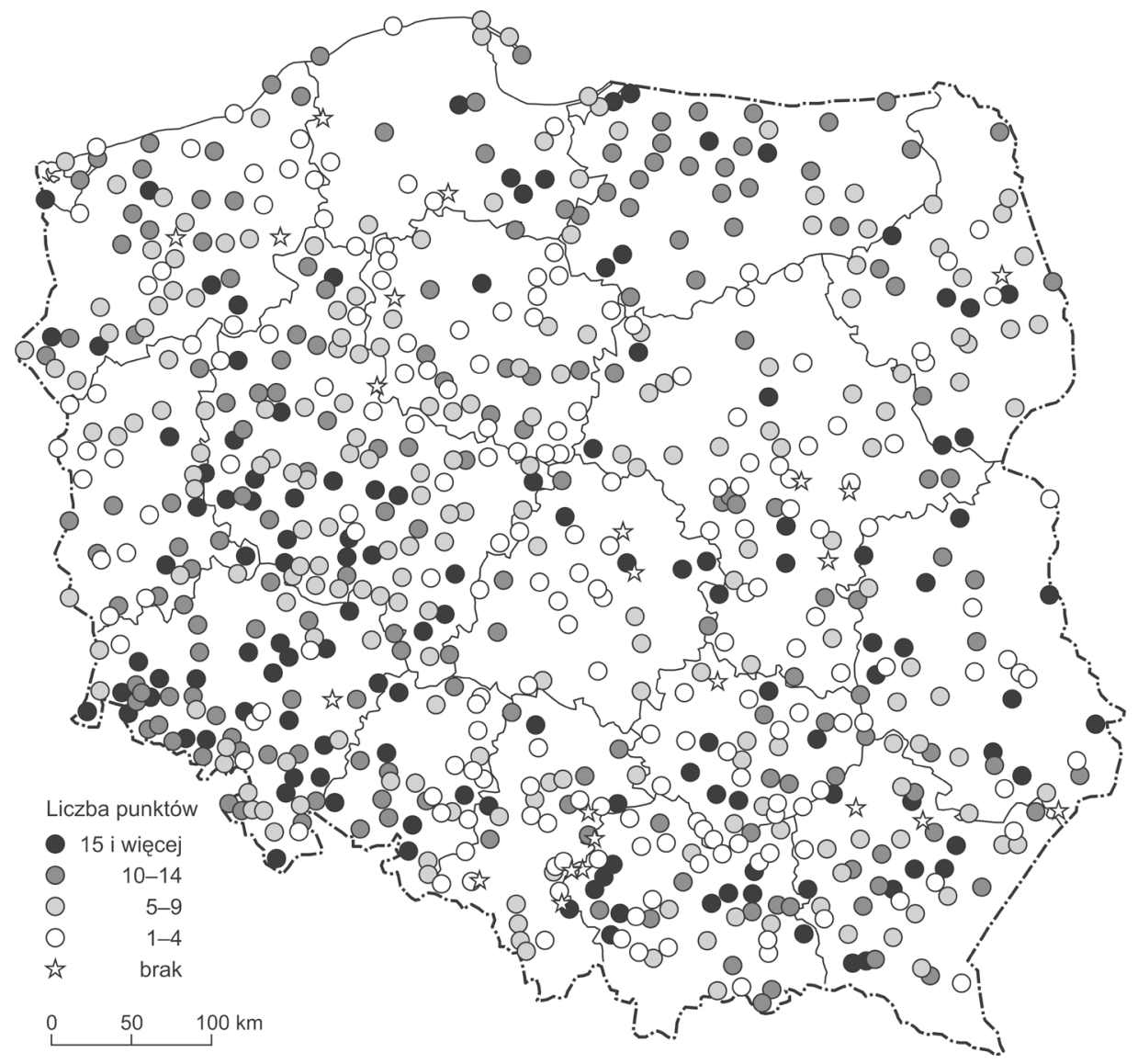

Rysunek 4. Waloryzacja małych miast w Polsce pod względem zasobów zabytków nieruchomych (stan na 2019 r.) Źródło: opracowanie własne

przykładem miasta, które w proponowanej typologii uzyskało wysoką pozycję, jest Radłów w powiecie tarnowskim. Wprawdzie miasto to otrzymało prawa miejskie dopiero w 2010 r., jednak dawniej było własnością biskupów krakowskich, na przełomie XVII i XVIII w. powstał tam rynek, a między XIX i XX w. ratusz.

Przeprowadzona analiza wykazała, że tylko w 23 małych miastach w Polsce $(3,1 \%)$ nie ma w ogóle obiektów wpisanych do rejestru zabytków. Największy udział tych miejscowości w odniesieniu do ogólnej liczby miast danego województwa odnotowano w województwach śląskim i pomorskim (tab. 1). Zdecydowana większość z nich to miejscowości, które uzyskały prawa miejskie w XX w. i pełnią funkcję ośrodków górniczych, lokalnych ośrodków przemysłowych, a także węzłów komunikacyjnych, 





głównie kolejowych. Geneza niektórych z tych miejscowości sięga średniowiecza, jednak ich późniejsza historia, związana także ze zniszczeniami podczas II wojny światowej, spowodowała zanik dawnych układów urbanistycznych i zabytków. Wśród tych 23 miast znajdują się także nowe ośrodki, których powstanie wiąże się z gwałtownymi procesami suburbanizacji, np. Siechnice.

\section{Podsumowanie}

Atrakcyjność turystyczna małego miasta uwarunkowana jest różnymi czynnikami. Wynikają one m.in. z położenia geograficznego i warunków środowiska naturalnego, przeszłości historycznej, dawnych funkcji oraz związanych z tym zasobów dziedzictwa kulturowego, walorów architektonicznych oraz układu urbanistycznego. Współcześnie o możliwości przyciągnięcia turystów do miast decyduje znacznie więcej różnych elementów (Cellini, 2011; Faracik, Kurek, Mika, Pawlusiński, 2015; Stasiak, Śledzińska, Włodarczyk, 2016). Obecnie znaczenie mogą mieć nowe atrakcje turystyczne, wynikające głównie z pomysłowości i przedsiębiorczości lokalnych społeczności, np.: parki rozrywki, parki tematyczne, ośrodki spa and wellness, festiwale uliczne, filmowe, koncerty muzyczne, imprezy sportowe, targi, giełdy, spotkania biznesowe, kongresy, a także powstałe do ich obsługi nowoczesne obiekty i baza noclegowa, która sama w sobie może stanowić atrakcję turystyczną.

Zabytkowe obiekty, tradycyjne budownictwo czy krajobraz kulturowy zawsze stanowią pewien zbiór, z którego - przyjmując mniej lub bardziej obiektywne kryteria - wybiera się do ochrony to, co biorąc pod uwagę współczesne czasy, obowiązujące przekonania lub pewne okoliczności, jest najbardziej wartościowe (Purchla, 2013). Ochrona dziedzictwa w zakresie prowadzenia ewidencji zabytków, wpisywania nowych obiektów do rejestru oraz realizacji krajowego programu ochrony zabytków i opieki nad nimi jest obecnie jednym z zadań samorządów lokalnych. Prezentowanie ich jako produktów turystycznych może przyczynić się do aktywizacji i rozwoju turystycznego małych miast.

Produkty turystyczne związane $\mathrm{z}$ dziedzictwem historycznym mają duże znaczenie w rozwoju turystyki miejskiej i kulturowej, jednak jak już wspomniano, współcześnie nie są one głównym magnesem przyciągającym potencjalnych turystów, którzy oczekują czegoś więcej niż ładny krajobraz miejski i związane z tym doznania estetyczne. Ograniczanie turystyki miejskiej do dziedzictwa kulturowego nie znajduje uzasadnienia 
w obserwowanych współcześnie zjawiskach i procesach (Kurek, 2007). Coraz powszechniejszą formą ukazania walorów krajoznawczych jest tzw. żywa interpretacja, mająca na celu ożywienie obiektów, rekonstrukcję wydarzeń historycznych, pokazy i prezentacje, odtwarzanie typowych zajęć, obrzędów i tradycji przy wykorzystaniu technik aktorskich i replik kostiumów z danej epoki, co oddziałuje na wszystkie zmysły i emocje odbiorców (Stasiak, Sledzińska, Włodarczyk, 2016).

Miasto to nie tylko zabytki, ale również ważne obiekty turystyczne, jakimi są muzea, galerie, obiekty sportowe, centra handlowe i rozrywkowe oraz eventy, często związane z tradycją i kulturą lokalną. Mogą one stanowić jeden z najważniejszych powodów do odwiedzenia danej miejscowości. Aby małe miasta mogły zostać docelowymi punktami turystyki kulturowej, konieczne jest utrzymanie równowagi między identyfikacją unikatowych dóbr kultury a odpowiednim sposobem zaprezentowania ich opinii publicznej. Obiekty zabytkowe wydają się niedocenioną wartością samą w sobie, co może wynikać z jednej strony z niedostatecznej ich promocji, a z drugiej ze złego stanu ich zachowania. Wiele z wpisanych do rejestru obiektów wymaga pilnej renowacji. Dopiero wówczas mogą stać się realną atrakcją turystyczną.

\section{Bibliografia}

Bajgier-Kowalska, M., Rettinger, R. (2014). Tourism development in small cities on the example of Pistoia in Tuscany. Annales Universitatis Paedagogicae Cracoviensis, Studia Geographica, 5 (155), 77-87.

Cellini, R. (2011). Is UNESCO recognition effective in fostering tourism? A comment on Yang, Lin and Han. Tourism Management, 32 (2), 452-454.

Faracik, R., Kurek, W., Mika, M., Pawlusiński, R. (2015). „Stare” i „,nowe” wartości w turystyce miejskiej. Zarys problematyki. W: P. Trzepacz, J. Więcław-Michniewska, A. Brzosko-Sermak. A. Kłoś (red.), Miasto w badaniach geografów. T. 1 (s. 121-133). Kraków: Wydawnictwo Uniwersytetu Jagiellońskiego.

Jamieson, W. (1993). Planning for small town cultural tourism. W: P.L. Prematilleke (red.), Cultural tourism (s. 90-97). Colombo: Sri Lanka ICOMOS National Committee.

Jelonek, A. (1967). Ludność miast i osiedli typu miejskiego na ziemiach Polski od 1810 do 1960 r. Dokumentacja Geograficzna, 3 (4), 1-62.

Kaczmarek, J., Stasiak, A., Włodarczyk, B. (2010). Produkt turystyczny. Warszawa: Polskie Wydawnictwo Ekonomiczne.

Kruczek, Z., Kurek, A., Nowacki, M. (2012). Krajoznawstwo. Teoria i metodyka. Kraków: Wydawnictwo Proksenia.

Kurek, W. (2007). Turystyka. Warszawa: Wydawnictwo Naukowe PWN.

Kuśnierz, K., Kuśnierz-Krupa, D. (2015).Tourist function as an activating factor in small historic towns in the former Krakow region in the second decade of the $21^{\text {st }}$ century - selected problems. Journal of Heritage Conservation, 42, 61-70. 
Kwiatek-Sołtys, A. (2011). Small towns in Poland: Barriers and factors of growth. The $2^{\text {nd }}$ International Geography Symposium GEOMED 2010. Procedia-Social and Behavioral Sciences, 19, 363-370.

Kwiatek-Sołtys, A. (2017). Własność gruntów a poziom rozwoju małych miast w Polsce. Ujęcie typologiczno-przestrzenne. Kraków: Wydawnictwo Naukowe Uniwersytetu Pedagogicznego.

McMorran, C. (2008). Understanding the 'heritage' in heritage tourism: Ideological tool or economic tool for a Japanese hot springs resort? Tourism Geographies, 10 (3), 334-354.

Mika, M. (2011). Miasta jako obszary recepcji turystycznej. W: M. Mika (red.), Kraków jako ośrodek turystyczny (s. 15-34). Kraków: Instytut Geografii i Gospodarki Przestrzennej, Uniwersytet Jagielloński.

Purchla, J. (2013). Dziedzictwo kulturowe a kapitał społeczny. W: A. Rottermund (red.), Dlaczego i jak w nowoczesny sposób chronić dziedzictwo kulturowe? (s. 21-30). Pobrane z: http://www.unesco.pl/dlaczegoijak/index-21.html (2.09.2019).

Rajman, J. (1998). Od kasztelanii do powiatu. Ziemia chrzanowska na pograniczu Małopolski i Górnego Śląska. Cz. I: Na pograniczu śląsko-małopolskim w czasach staropolskich, Teki Krakowskie, 7, 109-136.

Rudan, E. (2010). The development of cultural tourism in small historical towns. Tourism $\mathcal{E}$ Hospitality Management, 10, 577-586.

Stasiak, A., Śledzińska, J., Włodarczyk, B. (2016). Wczoraj, dziś i jutro krajoznawstwa. W: A. Stasiak, J. Śledzińska, B. Włodarczyk (red.), Wspótczesne oblicza krajoznazsstwa (s. 9-27). Warszawa: Wydawnictwo PTTK „Kraj”.

Steele, J. (2010). Times have never been better for adding tourism to a small town's economic mix. Pobrane z: http://www.cfra.org/node/2504 (19.09.2019).

Warszyńska, J. (1970). Waloryzacja miejscowości z punktu widzenia atrakcyjności turystycznej (zarys metody). Zeszyty Naukowe Uniwersytetu Jagiellońskiego, Prace Geograficzne, $27,103-114$.

Zestawienia zabytków nieruchomych (2019). Pobrane z: https://nid.pl/pl/Informacje_ogolne/Zabytki_w_Polsce/rejestr-zabytkow/zestawienia-zabytkow-nieruchomych/ (31.10.2019).

\title{
ZASOBY DZIEDZICTWA KULTUROWEGO MAŁYCH MIAST W POLSCE I ICH ZNACZENIE W KRAJOZNAWSTWIE
}

\begin{abstract}
Abstrakt: Zabytki kultury materialnej są istotnym walorem krajoznawczym, decydującym o rozwoju turystyki poznawczej. Obiekty zabytkowe występują niemal we wszystkich małych miastach w Polsce. Są wśród nich obiekty wpisane na listę światowego dziedzictwa kultury UNESCO, znane zespoły zamkowe i pałacowe, jak również cenne budowle sakralne. Za szczególnie atrakcyjne uznaje się małe miasta z zachowanymi zabytkowymi układami urbanistycznymi. Zasoby dziedzictwa kulturowego obecne w wielu małych miejskich ośrodkach w Polsce wydają się niedocenioną wartością, na podstawie której można rozwijać funkcje turystyczne. Celem artykułu jest ukazanie, jak wiele obiektów dziedzictwa kulturowego wpisanych do rejestru zabytków znajduje się w małych miastach.
\end{abstract}

Słowa kluczowe: zasoby dziedzictwa kulturowego, małe miasta, Polska, turystyka krajoznawcza. 


\title{
THE CULTURAL HERITAGE RESOURCES OF SMALL POLISH TOWNS AND THEIR IMPORTANCE FOR CULTURAL TOURISM
}

\begin{abstract}
The historical monuments of cultural heritage are a significant asset in cultural tourism and they determine the development of cognitive tourism. Historical monuments can be found in almost all small towns in Poland. They include sites placed on the UNESCO world cultural heritage list, famous castle and palace complexes, as well as valuable sacred buildings. Particularly attractive destinations are small towns with a well-preserved historical urban layout. The cultural heritage resources found in many Polish towns seem to be underrated, although they can be a basis for developing tourism. The purpose of the article is to demonstrate how many cultural heritage sites registered as historical monuments can be found in small towns.
\end{abstract}

Keywords: cultural heritage resources, small towns, Poland, cultural heritage tourism. 